\title{
The Work Ethic of Chinese Culinary Entrepreneurs in Teluk Betung Selatan Sub-District, Bandar Lampung City
}

\author{
Ricadesta Amalia* ${ }^{*}$ Sudjarwo Trisnaningsih \\ Master of Social Science Education, Universitas Lampung, Indonesia
}

\begin{abstract}
This study aims to analyze the work ethic indicators and the aspects behind the formation of the work ethic of the Chinese culinary entrepreneurs in the Teluk Betung Selatan sub-district. This study employed the qualitative method with a phenomenological approach. Data collecting techniques that researchers used were observation, documentation, and interviews. The data analysis technique used was proposed by Miles and Huberman, which consisted of data collection, data reduction, data presentation, and drawing conclusion stages. The subjects of this study were Chinese culinary entrepreneurs in the Teluk Betung Selatan sub-district. This study found four aspects of the work ethic applied by the Chinese culinary entrepreneurs in the Teluk Betung Selatan sub-district. First, achievements through superior motivation. Second, build the future through visionary leadership. Third, create new values through creative innovation. Fourth, improve quality through human excellence, characterized by hard work and diligence, discipline, responsibility, excellent service, honesty, patience, and morals. Two factors influence the background that shapes the work ethic of the Chinese culinary entrepreneurs. First, the intrinsic factors, such as motivation, high interest, and a sense of wanting to get a big profit. Second, the extrinsic factors, namely religion, culture, and education.
\end{abstract}

Keywords: chinese work ethic, culinary entrepreneur, work ethic

DOI: $10.7176 / \mathrm{JEP} / 12-26-08$

Publication date:September $30^{\text {th }} 2021$

\section{Introduction}

Indonesia is a multicultural country where the population or society is diverse based on ethnicity, religion, and culture (Karmela \& Pamungkas, 2017; Samrin, 2014; Ulya, 2016). This diversity affects the number of interactions with various social, cultural, and economic dynamics (Budi, 2019; Faraby \& Faiza, 2014). One of the ethnic groups in Indonesia that excel in business is the Chinese (Abdi et al., 2015; Ratnawati et al., 2013).

The Chinese consider business as a means to achieve goals, increase self-esteem, and earn income. Their mentality and lifestyle are different from other ethnicities (Rohmah1 et al., 2017), including work ethic. Ethos is categorized as a basic attitude towards self and the world. Ethos is also a judgmental evaluative aspect (Abdullah, 2008; Takwim, 2012). Their work ethic affects the economic sector.

The Chinese are seen as having succeeded in dominating the economy in Indonesia even though their number is only 4\% (four per cent) of the total population of Indonesia (Siregar, 2018; Suhaida, 2015). They control 50\% (fifty per cent) of the Indonesian economy and control 37\% (thirty-seven per cent) of public companies (Nomura Research Institute in(Sahrah, 1995). the Chinese tend to dominate the economic power (Amalia \& Prasetyo, 2015; Siregar, 2018). At the local level, the Chinese influence the economy, making a big contribution in every area, including in Bandar Lampung City.

Lampung has long interacted with the Chinese. The distribution of the Chinese community in Bandar Lampung is in the Teluk Betung sub-district. The area has the Tay Hin Bio Temple, founded in 1850 AD by Po Heng after the eruption of Mount Krakatau in the Sunda Strait (Rekanza, 2019). Teluk Betung is a commercial centre. The Chinese in Teluk Betung became entrepreneurs, both in the field of goods and services.

The strong entrepreneurial culture cannot be separated from the traditions that have been institutionalized in their lives, such as managing family finances (Suhartini \& Renanta, 2007), form a joint system or group (Pertiwi et al., 2019), and a family-built business (Qibtiyah, 2019). Sociologically, the Chinese are built in the entrepreneurial tradition so that their mindset, behaviour, and attitude are already entrepreneurial-oriented. Moreover, entrepreneurship promises a better life economically, so entrepreneurship has been educated through involvement in various business activities run by the parents. Some of the Chinese elite families prepare their next generation to study abroad to master business skills.

Research on work ethic has been widely discussed, such as the influence of religiosity on the work ethic of Banjar traders (Budi, 2019), the work ethic of Madura ethnic traders (Faraby \& Faiza, 2014), Malay global economic work ethic (Ritawati, 2018) Javanese work ethic (Hidayatullah, 2019; Sugianti et al., 2020), the work ethic of the Acehnese (Sari, 2018), and Sundanese work ethic (Gumilar \& Sahidin, 2019). However, there are very few studies that discuss the Chinese wor ethic, including the Chinese work ethic in Jakarta (Reinhard, 2014), Semarang (Amalia \& Prasetyo, 2015), Pekan Baru (Princess \& Kadarisman, 2019), Yogyakarta (Joseph, 2017), and Jember (Rohmah1 et al., 2017).

The lack of research that discusses the Chinese work ethic encouraged the researchers to conduct this 
study. Moreover, there has been no previous research examining the Chinese work ethic, especially in the Bandar Lampung area. Therefore, this study discusses the Chinese work ethic in the Bandar Lampung area. This study focuses on the Chinese culinary entrepreneurs in the Teluk Betung Selatan sub-district.

\section{Research Method}

This study used the qualitative method with a phenomenological approach. The qualitative method was used in this study because the collected and analyzed data were qualitative. The steps of the phenomenological approach in this study are depicted in Figure 1.

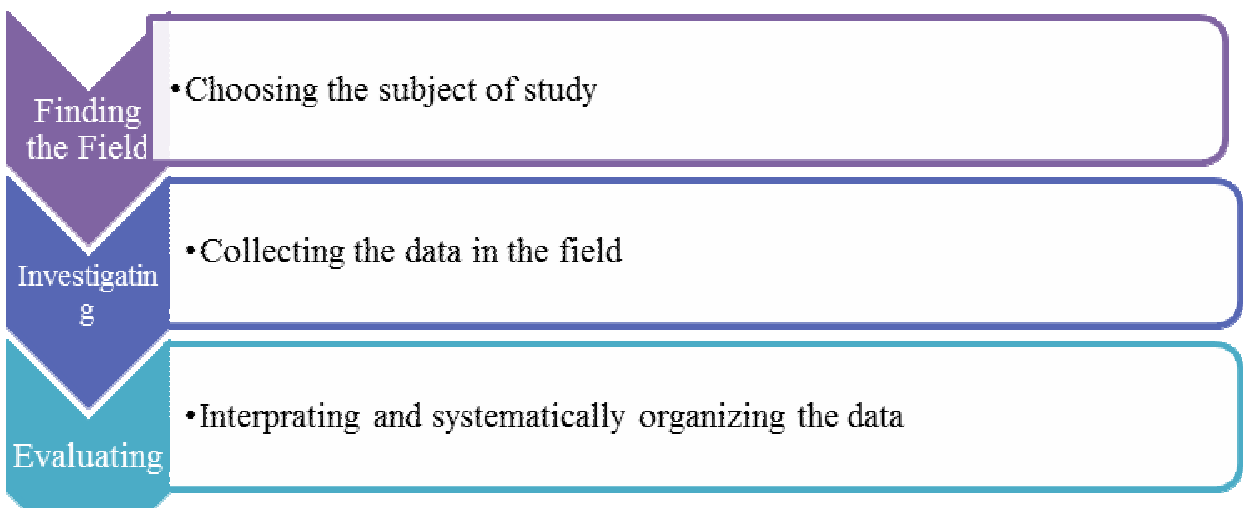

Figure 1. The Steps of Phenomenology Approach

This study was conducted in the Chinatown area of Teluk Betung Selatan sub-district, Bandar Lampung City. The research subjects were determined using a purposive technique, which was chosen with certain considerations and objectives by choosing someone who knows best about the expected results so that the researchers could explore the object or social situation (Sugiyono, 2011). The subjects of this study were Chinese culinary entrepreneurs in the Teluk Betung Selatan sub-district.

Data collection techniques applied in this study were interviews, observation, documentation, and literature studies. The validity of the data was tested using (1) credibility test, (2) transferability test, (3) dependability test, and (4) confirmability test (Sugiyono, 2011).

The data analysis technique proposed by Miles and Huberman was used in his study. The steps of data analysis are presented in Figure 2.

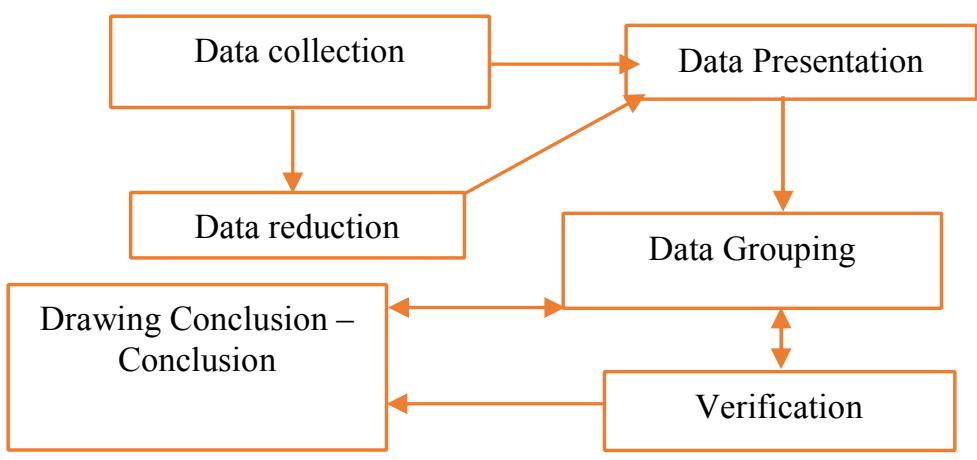

Figure 2. Data Analysis Proposed by Miles and Huberman

\section{Results and Discussion}

Researchers used interview, observation, and documentation techniques in collecting the data. The researchers interviewed the Chinese culinary entrepreneurs, cultural actors, community leaders, and the Indonesian Young Entrepreneurs Association (HIPMI). The interview technique used was a structured interview using question guidelines that have been prepared in advance. Also, the researcher used unstructured interview techniques to search deeper data.

The results show that the Teluk Betung Selatan sub-district Chinese culinary entrepreneurs have a work ethic and various attitudes or ways of running their business. Various habits or customs construct the work ethic and attitude passed down from generation to generation. In running their business, the Chinese culinary entrepreneurs develop various mature strategies. They have a high work spirit or work ethic so that the business can continue to develop as expected. The harder and smarter they are in trying, the better and faster the results 
will be. Table 1 presents the results of this study.

Table 1. Work Ethic Matrix and Factors Forming Work Ethic of the Chinese Culinary Entrepreneurs in Teluk Betung Selatan sub-district

\begin{tabular}{|c|c|c|c|}
\hline NO & $\begin{array}{l}\text { The Chinese Culinary } \\
\text { Entrepreneurs' Work Ethic }\end{array}$ & $\begin{array}{l}\text { Characteristics of Work } \\
\text { Ethic }\end{array}$ & Factors Forming the Work Ethic \\
\hline 1 & $\begin{array}{l}\text { Achievements through superior } \\
\text { motivation }\end{array}$ & $\begin{array}{ll}\text { - } & \text { Responsibility } \\
\text { - } & \text { Patient and honest }\end{array}$ & \multirow{4}{*}{$\begin{array}{ll}\text { 1. } & \text { Intrinsic Factor } \\
\text { - } & \text { Motivation } \\
\text { - } & \text { Desire for profit } \\
\text { 2. Extrinsic Factor } \\
\text { - Religion } \\
\text { - Culture } \\
\text { - Education }\end{array}$} \\
\hline 2 & $\begin{array}{l}\text { Building the future through } \\
\text { visionary leadership }\end{array}$ & $\begin{array}{ll}\text { - } & \text { Diligent } \\
\text { - } & \text { Work hard }\end{array}$ & \\
\hline 3 & $\begin{array}{l}\text { Creating new value through } \\
\text { creative innovation }\end{array}$ & $\begin{array}{ll}\text { - } & \text { Work with morals } \\
\text { - } & \text { Discipline }\end{array}$ & \\
\hline 4 & $\begin{array}{l}\text { Improving quality through human } \\
\text { excellence }\end{array}$ & - $\quad$ Provide good service & \\
\hline
\end{tabular}

Table 1 contains several aspects of the work ethic, the characteristics of the work ethic, and the factors that make up the work ethic. The following is the description of the above results.

\subsection{Work Ethic Indicators of the Chinese Culinary Entrepreneurs in Teluk Betung Selatan sub-district 3.1.1. Achievements through Superior Motivation}

the Chinese businessmen are known in Indonesia as scorers of achievements in the business world. They have superior motivation to do certain things to achieve goals. The superior motivation of these Chinese culinary entrepreneurs is reflected in their work ethic. The characteristics of the work ethic in this aspect are:

\subsubsection{Responsibility}

The work ethic of the Chinese culinary entrepreneurs in the Teluk Betung Selatan sub-district is the sense of Responsibility. They are responsible for the food they sell and the employees who have worked for years. They have a sense of caring for all customers by giving bonuses to their regulars.

\subsubsection{Honest and Patient}

The honesty and patience they instil in running the business are solely to increase the customers' sense of loyalty and loyalty to their culinary business. The Chinese culinary entrepreneurs apply an honest and patient attitude. Customers will not move to another place because they trust the culinary business.

They apply an honest attitude in choosing and processing food ingredients properly to produce good foods and satisfy the customers. Besides honesty, they also instil a patient attitude in running their business. They always instil a patient attitude when serving customers and dealing with different customers.

\subsubsection{Building the Future through Visionary Leadership.}

The second aspect of work ethic is building the future through visionary leadership. The Chinese culinary entrepreneurs who are successful in the business world have a high vision to change their lives for the better through their efforts and aspire to build a better future. The Chinese businessmen have the desire that all of their descendants should not live in hardship. Building the future with visionary leadership is defined as the work ethic who has the attitude and personality to take advantage of opportunities. People with this leadership style will always see the potential of the company or business. Therefore, Chinese entrepreneurs have a visionary leadership spirit. The characteristics of the work ethic possessed by the Chinese culinary entrepreneurs in Teluk Betung Selatan sub-district are:

\subsubsection{Hard Work and Diligent}

The first work ethic is the spirit of hard work in running a business. This spirit is related to the earnest effort that a person has at work. The hard work of the Chinese culinary entrepreneurs is not a momentary hard work attitude, but a mature hard work attitude. If a momentary hard work attitude is applied, then a person will meet many failures. The results of this study are in line with Rohmah's opinion (Rohmah et al., 2017) that the Chinese people are not easily discouraged in running their business, evidenced by the business they have established for many years.

The Chinese culinary entrepreneurs in Teluk Betung sub-district also apply a diligent attitude. For them, laziness is the most abstinent attitude because it will have a huge impact on business success. The Chinese culinary entrepreneurs think that at work, one must be diligent in achieving sales targets.

\subsubsection{Creating New Value through Creative Innovation.}

The third aspect of the work ethic is to create new value through creative innovation. A work ethic that has new values can encourage work enthusiasm to create creative innovations. People with this aspect will certainly produce new and creative innovations. This work ethic aspect has two professional indicators, namely, work as worship and work as an art. Based on the research results, the Chinese culinary entrepreneurs in the Teluk Betung Selatan sub-district have the following characteristics: 


\subsubsection{Work as a Moral Duty}

Work as a moral duty is based on the feeling that one must work and provide services to society or others. Indirectly, work also provides services to others. The form of service is reflected in their daily profession, which serves buyers. This form of service to others is clearly illustrated because food is a basic need for everyone. Working with morals is also described by the Chinese culinary entrepreneurs in Teluk Betung Selatan subdistrict by considering work as a routine that must be done sincerely and happily because it is a gift from God.

\subsubsection{Discipline}

The second work ethic possessed by the Chinese culinary entrepreneurs in the Teluk Betung Selatan sub-district is discipline. The discipline they apply is the discipline of time in running a business. For the Chinese entrepreneurs in the Teluk Betung Selatan sub-district, discipline is an important work ethic that must be applied in running a business. The benefits of running a business also depend on the discipline they have and the right use of time.

The Chinese culinary entrepreneurs discipline their time by opening and closing shops or restaurants according to their time. They try to open the shops as early as possible (before 8 a.m.) and close after 8 p.m. They apply this consistently because by opening the shops as soon as possible, no later than eight o'clock in the morning, there will be a blessing in itself rather than having to procrastinate. This is in line with the research conducted by Amalia and Prasetyo (Amalia \& Prasetyo, 2015) that the Chinese traders value time in their activities.

\subsubsection{Improving Quality through Human Excellence}

The fourth aspect of the work ethic is improving quality through human excellence, consisting of two indicators: honorr and work is service. Based on the results of the study, these two indicators are found in the Chinese culinary entrepreneurs with the following characteristics:

\subsubsection{Good Service}

According to the Chinese culinary entrepreneurs, being smart in running a business is considered lacking. Entrepreneurs must also be smart in providing good service to customers to make the business smoother and have more customers. Every entrepreneur running a business must provide good service because service is a framework for maintaining and forming customer loyalty. Service is an activity carried out according to the interests of consumers, which will create a distinct impression. Therefore, good service is an important thing in running any business.

The form of good service provided by the Chinese culinary entrepreneurs is reflected in their attitude towards customers. The Chinese culinary entrepreneurs always show a friendly attitude towards their customers. This attitude is also applied by all employees who serve customers with a friendly and respectful attitude. Besides their friendly attitude, the Chinese culinary entrepreneurs also have a surefire way by providing many attractive offers every week. The offers given are usually discounted prices or certain bonuses. These offers are made to attract the attention of customers. According to the Chinese culinary entrepreneurs, good service is proof of a high commitment to running a business to achieve success.

\subsection{Factors Shaping the Work Ethic of the Chinese Culinary Entrepreneurs in Teluk Betung Selatan Sub- District}

The Chinese culinary entrepreneurs have a high work ethic nurtured since childhood and has become an entrenched habit for them. Tenacity in work is something you must have if you live in a foreign area. The work ethic of the Chinese culinary entrepreneurs certainly does not appear by itself. Of course, there are things behind the formation of this work ethic. There are two groups of factors that affect a person's work ethic: intrinsic and extrinsic (Hadi, 2013). The factors obtained from the research data are presented in Figure 3. 


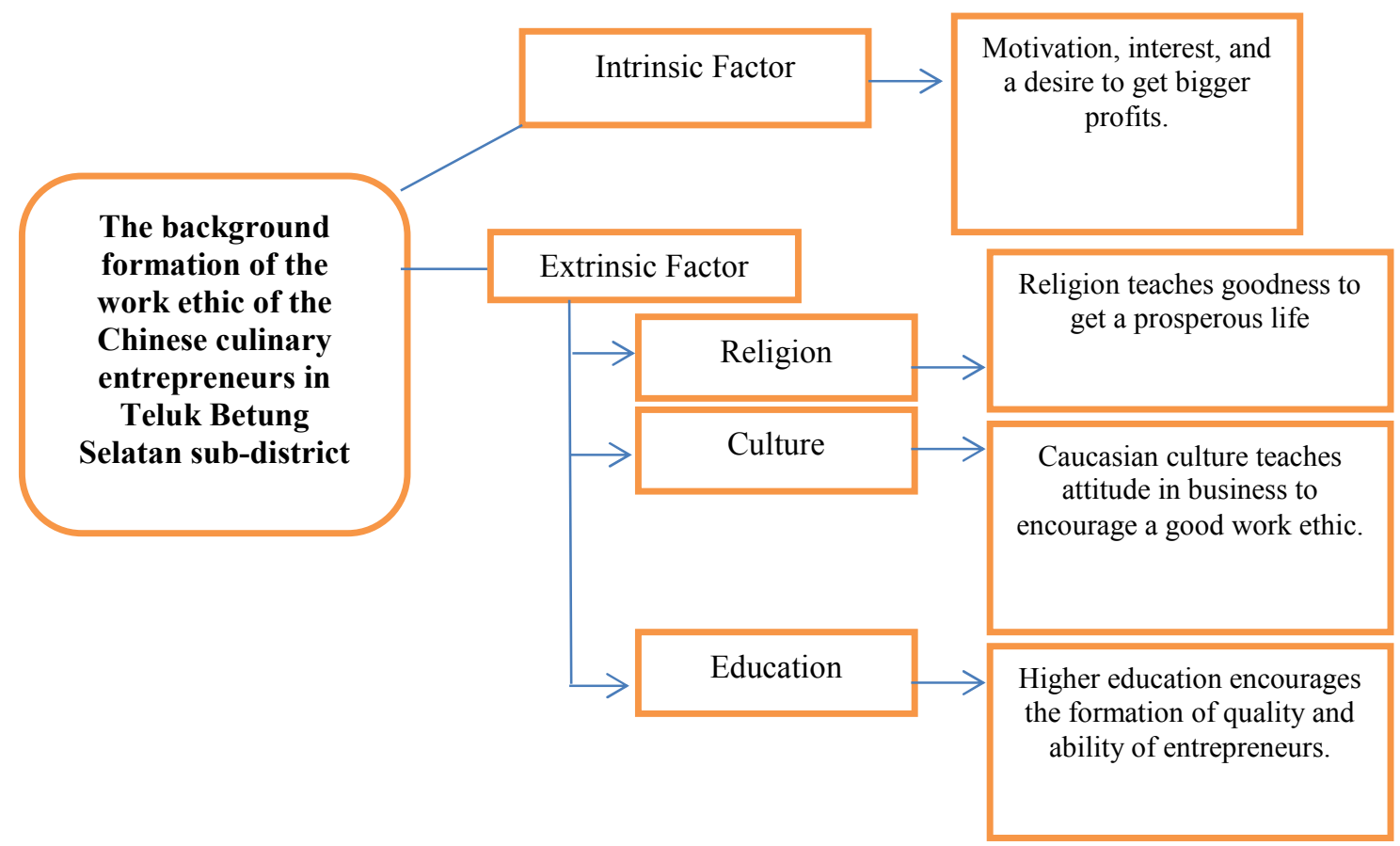

Figure 3. The Background Formation of Chinese Culinary Entrepreneur's Work Ethic

Figure 3 explains the reasons behind the formation of the work ethic of the Chinese culinary entrepreneurs. Further explanation is described as follows:

\subsubsection{Interest and Motivation of Wanting to Obtain Bigger Profits}

The intrinsic factors behind the work ethic of the Chinese culinary entrepreneurs in the Teluk Betung Selatan subdistrict are high interest or motivation. This interest or motivation is related to the willingness and enthusiasm in running a business because people who have a high work ethic are highly motivated individuals (Novliadi, 2009). Based on this opinion, the Chinese culinary entrepreneurs in the Teluk Betung Selatan sub-district have a high work ethic reflected in their enthusiasm, interest, and motivation.

High interest and motivation affect the work ethic of the Chinese culinary entrepreneurs through their persistent attitude in running a business. The results of this study indicate that several Chinese culinary entrepreneurs have changed their types of work. However, because it is not based on their skills and interests, they end up failing. Culinary business is suitable with their interests and abilities. The sense of persistence shown is a sense of unyielding. They have failed many times in running their business, but they keep getting up and moving forward. Besides the interest that underlies the work ethic of the Chinese culinary entrepreneurs in the Teluk Betung Selatan sub-district, they also desire to obtain bigger profits. This feeling makes the Chinese culinary entrepreneurs cultivate the characteristics of being active and diligent in working because they fear experiencing hardship and falling into poverty if they do not work seriously. They also work for the benefit of their children and grandchildren. They are currently working hard so that later, their descendants can enjoy the fruit of their labour.

\subsubsection{Religion}

The second background is an irrelevant factor, namely religion. Religion is believed to influence an entrepreneur to have a high work ethic. Every effort made by humans is inseparable from the religion or belief they hold. It is undeniable that religion can affect the human character.

Every work carried out by the Chinese entrepreneurs is always based on religious teachings. The religion they adhere to is Buddhism. Before opening the shop, they held morning prayer because it is sacred and cannot be removed from human life. They also pray and ask for health, luck, prosperity, and success in running a business.

Every work carried out by the Chinese entrepreneurs is always based on religious teachings. Buddhism also teaches that wealth that is amassed in a spirit and lawful manner without violence can make a person happy. Through these religious teachings, a high work ethic can be formed.

\subsubsection{Culture and Education}

The Chinese culinary entrepreneurs for generations, such as the teachings of philosophy Confucianism. The success of the Chinese community in doing business is related to these beliefs. For the Chinese culinary entrepreneurs, an entrepreneur with an advanced cultural value system will have a high work ethic. On the other hand, an entrepreneur with a conservative cultural value system will have a low work ethic and may even have no work ethic at all.

The cultural factor that influences the work ethic of Chinese culinary entrepreneurs is Conficianosm which 
is teaching about behaviour. Building a business community based on this philosophy is the same as building a business concept based on culture. One of the teachings applied by the Chinese culinary entrepreneurs in the Teluk Betung Selatan sub-district is a friendly attitude to customers and a sense of tolerance between religious communities. For example, when they run a business, both culinary and trade, they maintain a very good relationship with their partners and their customers. They also have an excellent religious tolerance with local people and followers of other religions.

Education is also the background that influences the work ethic of the Chinese culinary entrepreneurs in the Teluk Betung Selatan sub-district. Higher education affects the quality and ability to manage a business. They must also have people who can help their business run according to their wishes to achieve success.

This study indicates that there are many indicators of work ethic owned by the Chinese culinary entrepreneurs, such as hard work, patience, diligence, honesty, and others. The results are relevant to Amalia and Prasetyo's opinion (Amalia \& Prasetyo, 2015) that the Chinese traders' work ethics are hard work, frugal, honest, disciplined, and independent. Rohmah (Rohmah1 et al., 2017) reveals that Chinese people tend not to give up on running their businesses. This study and previous studies reveal that Chinese people have several work ethics that they uphold in entrepreneurship.

Previous research has discussed the work ethic of Chinese entrepreneurs in entrepreneurship. However, the previous research did not fully explain the factors that influence the formation of the work ethic. Therefore, the novelty of this study is the discussion of the factors that cause the formation of the work ethic. It is expected that this study can complement previous research that has not discussed the factors that construct the work ethic.

\section{Conclusion}

Based on the results of research and discussion, it can be concluded that the Chinese culinary entrepreneurs in the Teluk Betung Selatan sub-district have several work ethics. The work ethics are preserved from generation to generation, such as 1) achievements through superior motivation, 2) building the future through visionary leadership, 3) creating new values through creative innovation, and 4) improving quality through human excellence. These aspects have the following characteristics: hard work and diligence, discipline, high Responsibility for work, good service to customers, honest, patient, and working with morals. The background behind the formation of the work ethic of the Chinese culinary entrepreneurs is the intrinsic factor, namely high motivation or interest and a sense of wanting to get bigger profits. The second factor is the extrinsic factors, namely religious, cultural, and educational factors.

\section{References}

Abdi, F. F., Hafiar, H., \& Novianti, E. (2015). Perilaku komunikasi etnis Tionghoa peranakan dalam bisnis keluarga. Jurnal Komunikasi, 9(2), 105-118.

Abdullah, T. (2008). Agama, etos kerja dan perkembangan Ekonomi. Yayasan Obor Indonesia.

Amalia, F., \& Prasetyo, K. B. (2015). Etos budaya kerja pedagang etnis Tionghoa di pasar Semawis Semarang. Solidarity, 4(1).

Budi, I. S. (2019). Pengaruh religiusitas terhadap etos kerja pedagang Banjar di Pasar Sudimampir Banjarmasin. Jurnal Ekonomi Syariah Dan Hukum Ekonomi Syariah, 5(2), 102-110.

Faraby, M. E., \& Faiza, S. I. (2014). Etos kerja pedagang etnis madura di pusat grosir Surabaya ditinjau dari etika bisnis Islam. JESTT, 1(3), 178-193.

Gumilar, S., \& Sahidin, A. (2019). Etos kerja Urang Sunda: Ti bihari ka kiwari. Al-Tsaqafa: Jurnal Ilmiah Peradaban Islam, 16(2), 237-246. https://doi.org/10.15575/al-tsaqafa.v16i2.5832

Hadi, L. S. (2013). Aspek-aspek etos kerja dan faktor-faktor yang mempengaruhinya. Politeknik Keuangan Negara STAN.

Hidayatullah, M. S. (2019). Etos kerja orang Jawa di Kecamatan Makassar. Jurnal Kajian Sosial Dan Budaya, $3(2), 1-9$.

Karmela, S. H., \& Pamungkas, S. (2017). Kehidupan sosial ekonomi orang-orang Tionghoa di Kota Jambi. Jurnal Ilmiah Dikdaya, 7(1).

Novliadi, F. (2009). Hubungan antara organization-based self esteem dengan etos kerja. Universitas Sumatera Utara.

Pertiwi, U. N., Bosra, M., \& Asmunandar, A. (2019). Pedagang etnis Cina di Pattallassang Kabupaten Takalar 1971-2017. Jurnal Pattingalloang, 6(2), 1. https://doi.org/10.26858/pattingalloang.v6i2.10781

Putri, S. H., \& Kadarisman, Y. (2019). Etos kerja pedagang etnis Tionghoa dan keberhasilannya dalam berdagang dikelurahan Sago kecamatan Senapelan kota Pekanbaru. JOM FISIP, 6(1).

Qibtiyah, M. (2019). Tingkah laku ekonomi-politik dalam hegemoni agama dan budaya. Jurnal Studi Sosial Dan Politik, 3(1), 55-68. https://doi.org/10.19109/jssp.v3i1.4068

Ratnawati, R., Syah, I., \& Arif, S. (2013). Kebijakan pemerintah republik Indonesia tentang dwikewarganegaraan etnis Tionghoa pada masa demokrasi liberal. Jurnal Pendidikan Dan Penelitian 
Sejarah (PESAGI), 1(1), 1-8.

Reinhard, S. (2014). Gambaran etos kerja pada pedagang etnis Tionghoa di Jakarta. PSIBERNETIKA, 7(1), 6578.

Rekanza, H. (2019). Imlek: Kunjungi vihara Thay Hin Bio, tertua dan bersejarah di Lampung. Lampungpro.

Ritawati, R. A. (2018). Etos kerja dalam ekonomi global (Kasus Masyarakat Muslim Melayu Palembang). NURANI, 18(1), 73-86.

Rohmah1, A. N., Widodo, J., \& Djaja, S. (2017). Perilaku wirausaha pedagang etnis Cina di jalan Samanhudi Kabupaten Jember. Jurnal Pendidikan Ekonomi: Jurnal Ilmiah Ilmu Pendidikan, Ilmu Ekonomi, Dan Ilmu Sosial, 11(1), 8-15.

Sahrah, A. (1995). Identitas etnik dan nilai kerja karyawan Tionghoa asli da Tionghoa peranakan. APIO.

Samrin, S. (2014). Konsep pendidikan multikultural. Al-TA'DIB: Jurnal Kajian Ilmu Kependidikan, 7(2), 120140.

Sari, N. (2018). Integrasi agama dan budaya Aceh dalam pembentukan etos kewirausahaan (studi kasus HIPMI dan KPMI kota Langsa). KITABAH, 2(2), 226-245.

Siregar, A. P. (2018). Perilaku ekonomi Etnis Cina di Indonesia sejak tahun 1930-an. Jurnal Education and Development, 6(3), 6-11. http://journal.ipts.ac.id/index.php/ED/article/view/743

Sugianti, Syamsumarlin, \& Raemon. (2020). Etos kerja orang jawa dalam mengelola usaha warung makan di kota kendari. KABANTI: Jurnal Sosial Dan Budaya, 4(1), 41-61.

Sugiyono. (2011). Metode penelitian kuantitatif dan kualitatif. Alfabeta.

Suhaida, D. (2015). Orientasi politik masyarakat etnis Tionghoa Kota Pontianak dalam penguatan komitmen kebangsaan. Khazanah Pendidikan: Jurnal Ilmiah Kependidikan, 8(2), 1-12.

Suhartini, D., \& Renanta, J. A. (2007). Pengelolaan keuangan keluarga pedagang Etnis Cina. Jurnal Riset Ekonomi Dan Bisnis, 7(2), 70-81. http://ejournal.upnjatim.ac.id/index.php/rebis/article/view/60

Takwim, R. I. (2012). Pengaruh konflik dan motivasi kerja terhadap etos kerja dan implikasinya pada kinerja karyawan. IMAGE: Jurnal Riset Manajemen, 1(1), 84-95.

Ulya, I. (2016). Pendidikan Islam multikultural sebagai resolusi konflik agama di Indonesia. FIKRAH, 4(1), 20. https://doi.org/10.21043/fikrah.v4i1.1663

Yusuf, M. S. (2017). Etika bisnis komunitas Tionghoa muslim Yogyakarta. Religia, 14(1), $57-73$. https://doi.org/10.28918/religia.v14i1.33 